\title{
Synthesis of Remdesivir (GS-5734) - A Candidate for the Treatment of Ebola and COVID-19 Infections
}

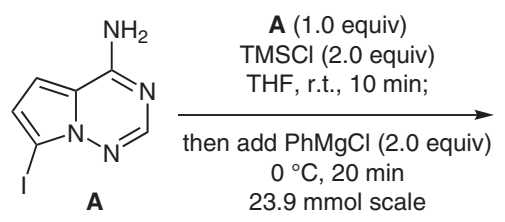

A<smiles>Cc1ccc2c(N(C)S(C)(=O)=O)ncnn12</smiles>

$[B]^{*}$

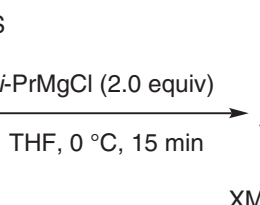<smiles>Cc1cc2c(N(C)S(C)(=O)=O)ncnn2c1C</smiles>

$[\mathrm{C}]^{*}$

* [ ] denotes a product used in the next step without further purification.<smiles>Nc1ncnn2c(C3(O)OC(COCc4ccccc4)[C@H](Oc4ccccc4)[C@H]3OCc3ccccc3)ccc12</smiles>

Category

Synthesis of Natural

Products and

Potential Drugs

\section{Key words}

remdesivir

GS-5734

COVID-19

C-nucleoside

phosphoramidate prodrug

cyanation

pyrrolotriazinamine<smiles>N#C[C@]1(c2ccc3c(N)ncnn23)O[C@H](CO)[C@@H](O)[C@@H]1O</smiles>

$\mathrm{Me}_{2} \mathrm{C}(\mathrm{OMe})_{2}$ (4.8 equiv) $\underset{\begin{array}{c}\text { acetone, r.t. to } 45^{\circ} \mathrm{C}, 1 \mathrm{~h} \\ \text { 99\% }(20 \mathrm{mmol} \text { scale })\end{array}}{\stackrel{\mathrm{H}_{2} \mathrm{SO}_{4} \text { (1.3 equiv) }}{\longrightarrow}}$

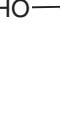<smiles>CC[C@H]1O[C@@](C)(c2ccc3c(N)ncnn23)[C@H]2OC(C)(C)O[C@@H]21</smiles>
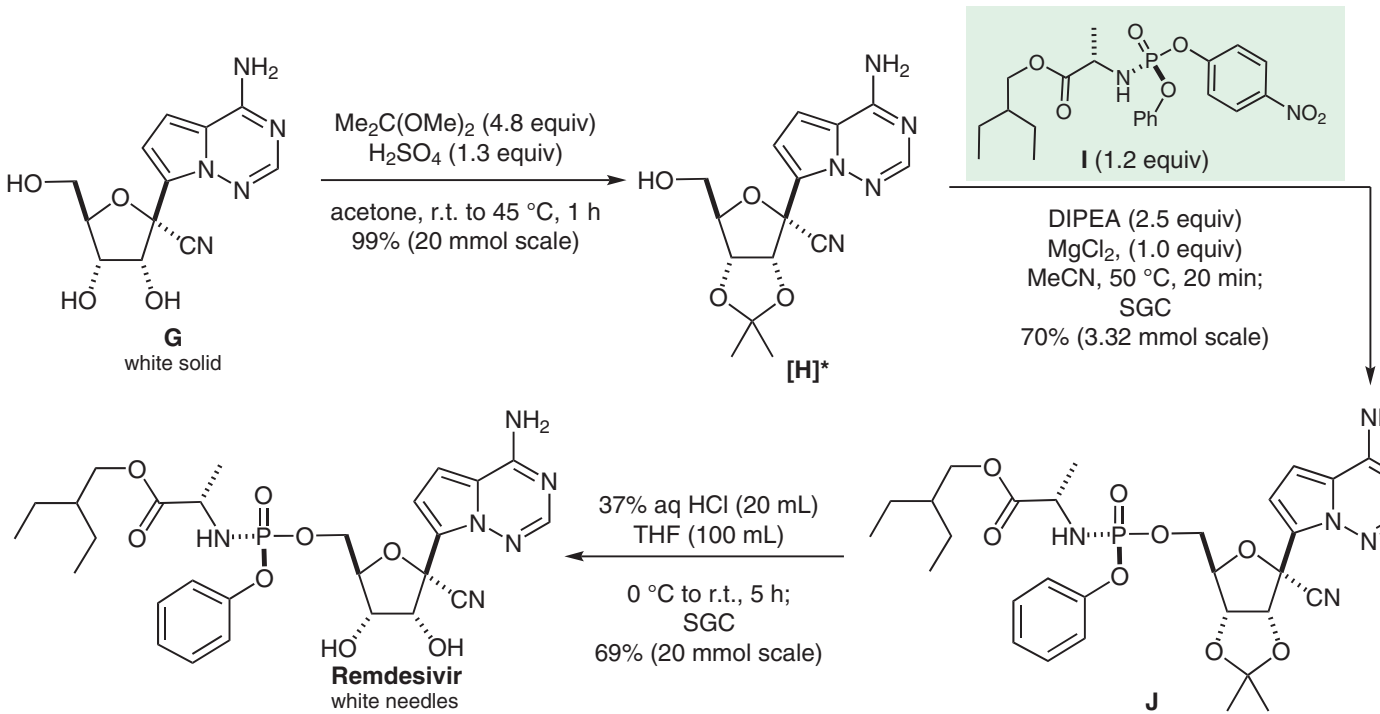

$69 \%$ (20 mmol scale)

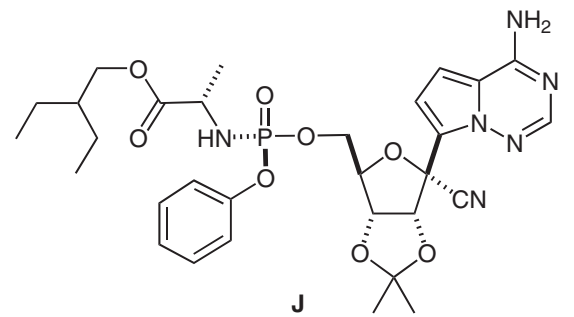

Significance: Remdesivir (GS-5734) is a C-nucleoside phosphoramidate prodrug of an adenosine analogue discovered by workers at Gilead, that is of intense interest for the treatment of Ebola virus disease, COVID-19, and other lethal viruses. It is an RNA-dependent RNA polymerase inhibitor.
Comment: The key step in the short synthesis depicted entails the construction of 1 '-cyano $\mathrm{C}$-glycoside $\mathbf{F}$ by reaction of $\mathrm{O}, \mathrm{O}$-acetal $\mathbf{E}$ with trimethylsilylcyanide ( $d r>95: 5)$. The presence of the 1 '-cyano modification was critical in providing selectivity toward viral polymerases. See also: D. Siegel et al. J. Med. Chem. 2017, 60, 1648. 